\title{
Small Business Growth and Performance
}

\section{Samuel Adomako ${ }^{1}$ and Kevin F. Mole ${ }^{2}$}

1. Entrepreneurship Institute, King Fahd University of Petroleum and Minerals, Dhahran, Saudi Arabia.

\section{Warwick Business School, University of Warwick, Coventry CV4 7AL UK}

\begin{abstract}
Research on business growth has blossomed, yet scholars often complain face the difficulty of distililing a clearer pitcure of the business growth phenomenon. This paper attempts to overcome this limitation by reviewing and synthesizing extant research on business growth. First, we begin by examining Penrose's view of firm growth. Second, we highlight how business growth is measured; these are absolute or relative change and growth as a process. Third, we explore theories of business growth; integrated models-theories that explain the factors that drive business growth and (2) stage models which view business growth as a series of phases or stages of development through which a firm must pass in its life-cycle. Fourth, we examine modes of business growth; these are organic vs. acquisition growth, growth through networks and alliances and growth through internationalization. Fifth, we examine drivers and constraints to business growth. We conclude the review by pointing out areas of harmony and contention in the literature, from which we suggest opportunities for future research.
\end{abstract}

Key words: Entrepreneurship, determinants, constraints, growth, performance

\section{Introduction}

Entrepreneurship, economics and strategy scholars have studied business growth for a number of years (e.g., Delmar, 1997; Coad, Segarra, and Teruel, 2016; Davidssson and Wiklund, 2000; Delmar and Wiklund, 2008; McKelvie and Wiklund, 2010). Despite these substantial scholarly efforts in business growth, theoretical developments have been notably slow (Delmar, 1997; Davidssson and Wiklund, 2000; McKelvie and Wiklund, 2010) making it difficult to distil a clearer picture of the small business growth phenomenon (Storey, 1994; Ardishvili, et al., 1998; Wiklund, 1998). Extant reviews have accounted for this negative status quo in business growth research suggesting that, despite many scholarly studies on business growth, our knowledge on the phenomenon is still limited (e.g. Weinzimmer, Nystrom and Freeman, 1998; Davidsson and Wiklund, 2000; MacPherson and Holt, 2007; 
Coad, 2007; Shepherd and Wiklund, 2009; McKelvie and Wiklund, 2010). The difficulty in distilling a clearer picture of the business growth phenomenon has been attributed to how scholars approach the theoretical and epistemological issues and interpretations; operationalisation; empirical contexts; modelling and analysis of the small business growth literature (Davidsson, Achtenhagen and Naldi, 2010).

The focus of this paper is, therefore, to contribute to further understanding of business growth by reviewing extant literature. To achieve this objective, this review is organized as follows: First, we highlight Penrose theory of firm growth. Second, we examine the evidence of how business growth is measured. Third, we review evidence relating theories of business growth; (1) integrated models and (2) stage models. Fourth, we review what is known about modes of business growth. Fifth, we examine drivers and constraints to business growth. In the final section, we highlight areas of consensus and contention.

\section{Penrosean view of firm growth}

Penrose's (1959/1995) Theory of the growth of the firm has received overwhelming scholarly support (e.g., Garnsey, 1998; Mahoney and Michael, 2005; Pitelis, 2007; Lockett et al., 2011; Obeng, Robson, and Haugh, 2014; Naldi and Davidsson, 2014). These are all substantial and critical empirical works which have attempted to use Penrose's theory of growth as a theoretical lens to explain small business growth. According to Penrose's (1959: 217) theory, the process of firm growth is influenced by the extent of the firm's resources, that the "amount of resources administered by a firm has in itself a significant influence on the opportunities for expansion open to the firm". This suggests that larger firms or firms with access to more resources tend to grow more rapidly than smaller firms. 
The entrepreneurship and small business literature recognises resources as physical, financial and human capital resources (Obeng, Robson, and Haugh, 2014). The contribution of Penrose's resource based theory in explaining small business growth can be attributed to the importance the theory places in distinguishing between the internal resources of businesses and their capacity to achieve high growth (Davidsson and Wiklund, 1999). That is, the resource-based view of the firm is based on the assumption that the internal resources of the business can affect its capacity to achieve higher growth (Davidsson and Wiklund, 1999). In her seminar work, Penrose (1995: 217) stated that "[the] amount of resources administered by a firm has in itself a significant influence on the opportunities for expansion open to the firm'. Similarly, Naldi and Davidsson (2014: 3) argued that entrepreneurship is key to the expansion process and that "expansion is triggered by the identification and exploitation of productive opportunities by entrepreneurial managers',. This is consistent with the strategic perspective which suggests that small firms should focus their attention on the strategic events and concentrate on utilisation of their limited resources so as to achieve sustained growth (Wernerfelt, 1984; Barney, 1991).

Indeed, wider scholarly enquiry on RBV (e.g., Wernerfelt, 1984; Barney, 1986, 1991) emanated from Penrose's (1959) seminal work which has contributed immensely to the strategic management literature. The RBV views organisations as bundles of resources. For example, assets, capabilities, organisational resources, information and knowledge can be classified as resources within an organisation.

Several empirical studies have highlighted the importance of the internal resources of the firm to the achievement of competitive advantage over its rivals (e.g., Wernerfelt, 1984; Barney, 1991). These resources are important for generating competitive advantage (Penrose, 1959; Barney, 1991). Accordingly, Barney (1991: 102) stressed that to achieve a 
competitive advantage, a firm should "implement value creating strategy not simultaneously being implemented by any current or potential competitors'.

However, some scholars suggest that while resources are important to achieving competitive advantage, firms do not have to own these resources themselves (Dhanaraj and Beamish, 2003). Instead, firms can form alliances with other organisations by establishing trade relationships and inter-firm alliances (Hessels and Parker, 2013). Thus, the RBV provides a useful theoretical lens for explaining how small businesses can gain competitive advantage and enhance firm performance through leveraging external networks (Street and Cameron, 2007).

It is arguable that Penrose's contribution fails to fully address the issue of knowledgerelated intra-firm advantages. Penrose took for granted that knowledge-related intra-firm advantages predict firm growth. Yet, this is not clear in her theory. A contentious issue is to pose a question as to why firms do not sell their (intangible) assets in the open market (Pitelis, 2009). Clearly, it can be argued that there are differential capabilities; i.e. firms are better in making use of their own assets than other firms (i.e. the market). Yet, Penrose did not discuss this issue in the theory of the growth of the firm.

\section{Measuring business growth}

Measuring business growth has generated diverse views (e.g., Birley and Westhead, 1990; Weinzimmer, et al., 1998; Delmar, 2000; Shepherd and Wiklund, 2009; Achtenhagen, Naldi and Melin, 2010). Scholars have measured business growth from two main perspectives: change in amount and growth as a process (Penrose, 1959; Davidsson, Achtenhagen and Naldi, 2010). In her seminal work, Penrose (1959: 1) positioned the phenomenon of growth as follows: "The term 'growth' is used in ordinary discourse with two different connotations. It sometimes denotes merely increase in amount; e.g., when one speaks of 
'growth' in output, export, sales. At other times, however, it is used in its primary meaning implying an increase in size or improvement in quality as a result of a process of development...in which an interacting series of internal changes leads to increase in size accompanied by changes in the characteristics of the growing object.' This suggests that growth can be defined as an increase in amount or as an internal process development.

From the change-in-amount perspective growth different measures of growth such as sales, employment, assets, physical output, market share and profits have been employed in the literature (e.g. Delmar, 1997; Wiklund, 1998; Ardishvili et al., 1998; Davidsson and Wiklund, 2000; Delmar, Davidsson \& Gartner, 2003; Barringer et al., 2005; Delmar and Wiklund, 2008). These measures offer particular advantages and disadvantages in distilling the picture of the phenomenon of growth (Delmar, 1997). Yet, there seems to be a controversy in the literature as to which indicator is appropriate in measuring business growth (Weinzimmer et al., 1998; Mckelvie and Wiklund, 2010). Indeed, the notion of growth as "increase in amount" dominates empirical studies that measure business growth in entrepreneurship field (Achtenhagen, Naldi and Melin, 2010). Thus, previous empirical development tends to place much emphasis on outcome-based predictors which denote an increase in in size or amount.

There is a growing consensus of the use of sales as a measure of growth over a time period of 5 years in the literature (e.g. Miller, 1987; Dunne and Hughes, 1996; Ardishvili et al., 1998; Weinzimmer et al., 1998; Barringer et al., 2005; Barkham et al., 1996). A major conclusion is that sales often precede other indicators (e.g. Flamholtz, 1986; Davidsson, Achtenhagen and Naldi, 2010). For example, it is the increase in sales that calls for increase in assets and employees which leads to higher profits or market share (Flamholtz, 1986). Other researchers contend that sales can be measured with ease across various countries and 
industry and also the preferred measure for business owners (e.g. Hoy, McDougall \& Dsouza, 1992). Owner-managers use sales figures most and sales figures are preferred by entrepreneurs (Barkham et al., 1996).

Another indicator that has received much attention in measuring growth is employment (Delmar, 1997). Scholarly studies mostly use relative employment growth over a three year period (Zahra, 1993; Vaessen and Keeble, 1995; Peters and Brush, 1996). However, according to Davidsson and Wiklund (2000) employment as an indicator of growth is highly relevant to policy makers because policy makers tend to focus on employment than sales growth of businesses within an economy. Yet, because some businesses employ outsourcing strategy, employment growth is not always highly related to sales growth (e.g. Delmar, Davidsson and Gartner, 2003; Chandler, McKelvie and Davidsson, 2009; Shepherd and Wiklund, 2009).

Indeed, the use of one indicator as a measure of growth may or may not actually reflect growth when used another indicator as a measure (Delmar, Davidsson and Gartner, 2003). Therefore, some scholars have advocated the use of multiple measures to account for variations in model testing and theory development (Weinzimmer et al., 1998). There appears to be no consensus or a universally accepted measure of business growth and inculcating multiple measures is likely to provide a complete picture of business growth. The use of multiple measures is likely to provide a way to test the robustness of any theoretical model (Delmar, Davidsson and Gartner, 2003). A major shortcoming of the use of multiple indicators is that the assumption of common cause may be incorrect (Delmar, Davidsson and Gartner, 2003). Further, some scholars are of the view that different growth measures and calculations of business growth influence model building and theory development differently and advocate for the use of a single measure of business growth 
(Chandler and Hanks, 1993; Delmar, 1997; Weinzimmer et al., 1998). Table 1 below summarises empirical studies and the ways growth is conceptualised. As can be seen from Table 1 below, sales and employment have been used extensively in measuring business growth in the literature. 
Table 1: Summary of Studies Measuring Business Growth

\begin{tabular}{|c|c|c|c|}
\hline Author(s) & How growth is measured & $\begin{array}{l}\text { Time-frame of the } \\
\text { study (in years) }\end{array}$ & Sample size \\
\hline Coad, Segarra, and Teruel (2016) & $\begin{array}{l}\text { Sales growth, employment growth and } \\
\text { productivity growth }\end{array}$ & 8 & 26660 \\
\hline Beck, Lu and Yang (2015) & Sales & 1 & 344 \\
\hline Capasso, Treibich and Verspagen (2015) & Employment & 4 & 13,236 \\
\hline Garcǐa-Posada and Mora-Sanguinetti (2014) & Sales and employment & 8 & $2,861,174$ \\
\hline Arregle et al., (2015) & Sales & 2 & 515 \\
\hline Federico and Capelleras (2015) & Sales & 14 & 926 \\
\hline Fafchamps et al., (2014) & Profits & 4 & 781 \\
\hline O’Cass and Sok (2014) & $\begin{array}{l}\text { Sales, profit, customer satisfaction and } \\
\text { financial growth }\end{array}$ & 1 & 171 \\
\hline Obeng, Robson and Haugh (2014) & Employment & 0.6 & 441 \\
\hline Mai and Zheng (2013) & Market share & 2 & 905 \\
\hline Schoonjans, Cauwenberge and Bauwhede (2013) & $\begin{array}{l}\text { Employment, net assets, and added value } \\
\text { growth }\end{array}$ & 5 & 108,241 \\
\hline Didier and Schmukler (2013) & Total assets, sales and employment & 20 & 214,271 \\
\hline Hamelin (2013) & Sales & 6 & 22,237 \\
\hline Anderson and Eshima (2013) & Sales, employment and market share & 1 & 207 \\
\hline
\end{tabular}


Table 1: (Continued)

\begin{tabular}{|c|c|c|c|}
\hline Author (s) & How growth is measured & Time-frame of study (in years) & Sample size \\
\hline Barringer, Jones and Neubaum (2005) & Sales and Employment & 3 & 100 \\
\hline Chandler and Baueus (1996) & Sales & 1 & 66 \\
\hline Bacchetti and Trovato (2002) & Financial growth & 8 & 4000 \\
\hline Carpenter and Petersen (2002) & Total assets & 3 & 372 \\
\hline Davidsson and Delmar (1997) & Employment & 1 & 11,748 \\
\hline Delmar, Davidsson and Gartner (2003) & Sales and Employment & 1 & 11,748 \\
\hline Freel and Robson (2004) & Employment & 3 & 1,347 \\
\hline Glancey (1998) & Employment & 1 & 38 \\
\hline Davidsson and Henkerson (2002) & Employment & 1 & 8,173 \\
\hline Kelley and Nakosteen (2005) & Sales Revenue & 11 & 67 \\
\hline Kangasharju (2000) & Employment & 7 & 26,057 \\
\hline Johnson, Conway and Kattuman (1999) & Employment & 2 & 75 \\
\hline
\end{tabular}


Table 1: (Continued)

\begin{tabular}{|c|c|c|c|}
\hline Author (s) & How growth is Measured & Time-Frame of study (Years) & Sample Size \\
\hline O’Gorman (2001) & Sales Turnover and Employment & 20 & 2 (Longitudinal study) \\
\hline Wiklund and Shepherd (2003) & Employment and sales & 3 & 326 \\
\hline Pena (2002) & Employment, sales and profit & 1 & 119 \\
\hline Reichstein and Dahl (2004) & Sales Turnover and employment & 1 & 9,000 \\
\hline Davidsson (1991) & Sales and employment & 3 & 322 \\
\hline Miller and Friesen (1983) & Sales and profit & 5 & 86 \\
\hline
\end{tabular}


Table 1: (Continued)

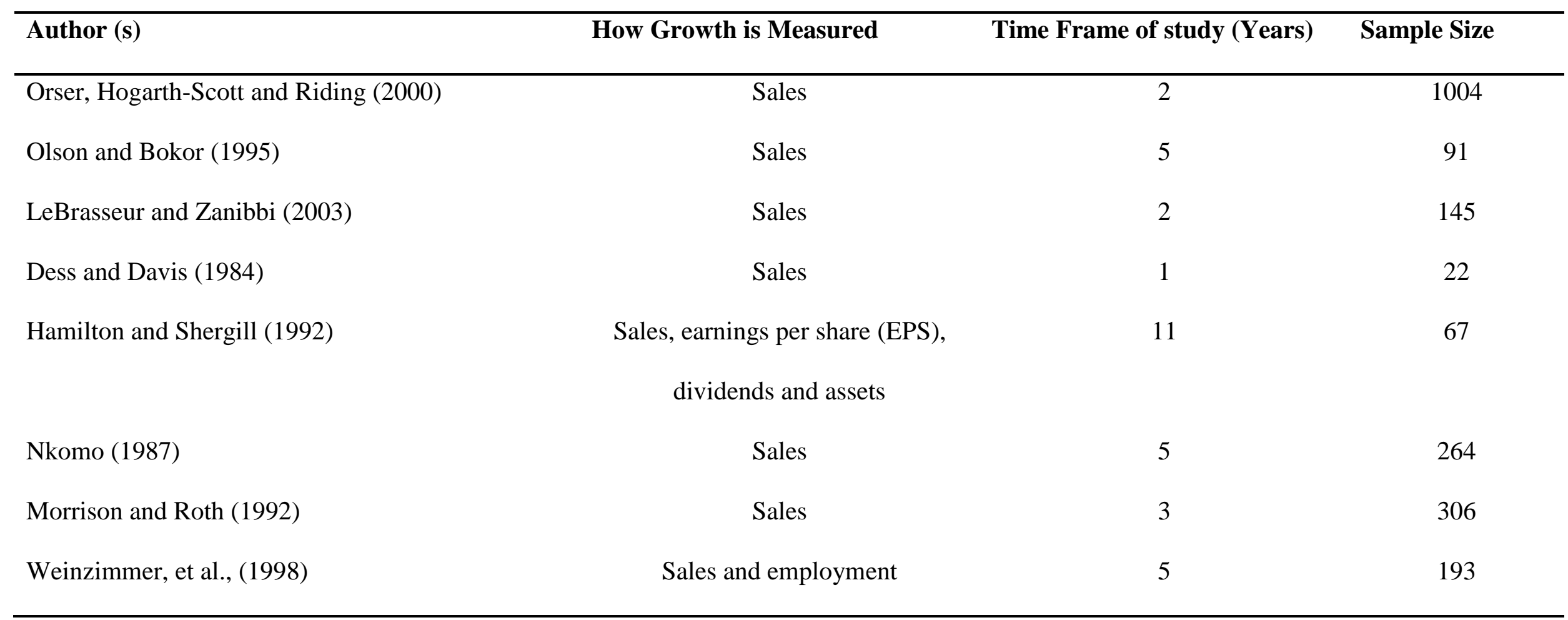




\section{Theories of business growth}

Business growth has much attention from scholars in the business literature (e.g. Storey, 1994; Smallbone and Wyer, 2000; Davidsson et al., 2002; Yasuda, 2005) with several studies attempting to explain the dynamics of business growth (e.g. Hanks \& Chandler, 1992; Hanks et al., 1993) and associating many factors with business growth (e.g. Orser et al., 2000; Sleuwaegen and Goedhuys, 2002; Davidsson et al., 2002; Obeng, Robson and Haugh, 2014). However, evidence from the literature indicates that various theories that predict business growth have been sparse and scattered (Garnsey, 1998). For example, Davidsson et al., (2002:1) described economic theories that predict business growth as 'crude and contradictory'. The reason may be that the literature is broad in scope (McMahon, 1998) and not confined to a single discipline.

Similarly, Penrose $(1959 ; 1995)$ indicated that many factors influence the growth of businesses and as such it is difficult to explain small businesses growth with a single one-fit all model. Theories of business growth can be broadly divided into two (1) integrated models-theories that explain the factors that drive business growth and (2) stage models which view firm growth as a series of phases or stages of development through which a firm must pass in its life-cycle.

\section{Integrated Models of Business Growth}

A growing list of internal and external factors that could affect business growth creates a challenge for studies that attempt to explain business growth. Several theories have been proposed to examine business growth and these include Gibrat's (1931) law of proportionate effect, Penrose's (1959) theory of firm growth, Jovanovic's (1982) learning theory, Storey's (1994) growth determinants model, Davidsson (1991) growth determinants model and Wiklund's (1998) growth model. These theories have received reasonable validity assessment 
in both advanced economies (e.g., Weinzimmer et al., 1998; Orser et al., 2000; Stam, 2010; Wiklund et al., 2009) and less developed market economies (e.g., Masakure et al., 2009; Obeng, Robson and Haugh, 2014). A point of convergence of most of these theories is that they suggest internal and external factors that could affect business growth. Notwithstanding the fact that a large body of research on business growth theories have been conducted, there seems to be a controversy as to which theory is appropriate in predicting business growth (e.g., Delmar, Davidsson and Gartner, 2003; Barringer et al., 2005; Delmar and Wiklund, 2008; Weinzimmer et al., 1998; Mckelvie and Wiklund, 2010). While individual studies cover an array of factors on different levels (e.g., Eisenhardt and Schoonhoven, 1990; Sandberg and Hofer, 1987), other scholars (e.g., Davidsson, 1991; Wiklund, 1998) attempt to formally integrate a broad range of growth drivers in a causal model. Thus, Davidsson's and Wiklund's models capture many factors with mediated relationships which represents an important area of examination in management research.

\section{Life-Cycle and Stage Models}

Apart from scholarly attempts to examining the factors that influence business growth, there is a body of literature that is concerned with growth processes. These models are often presented in the form of life cycle or stage models that encompass the entire lifespan of a business (e.g., Greiner, 1972; Churchill and Lewis, 1983; Gill, 1985; Scott and Bruce,1987; Kazanjian, 1988; Kazanjian and Drazin, 1989; O'Farrell and Hitchens, 1988a; Steinmetz, 1969; Gibb \& Davies, 1990a; Hanks, 1990a, 1990b; Kazanjian and Drazin, 1990; Hanks et al., 1991; Dodge and Robbins, 1992; Hanks et al., 1993; Hanks and Chandler, 1994; Barringer et al., 2005). These models attempt to explain the dynamic nature of growth of small businesses. 
The main difference between life-cycle models and stage models is that, whilst life-cycle models represent a cycle of emergence, growth, maturity and decline (e.g., Whetten, 1987; Adizes, 1989), stage models focus on the problems encountered by small businesses (e.g., Kazanjian, 1988; Walsh, 1988; Moy and Luk, 2003). According to Kimberly and Miles (1980) organisations are born, grown and declined. These have been referred to as life-cycle models. This raises contentious issues in economics, business and sociology (Penrose, 1952; Kimberly and Miles, 1980; McMahon, 1998).

Stage or developmental models, on the other hand, consider mainly the firm's development process (emergence, growth, maturity and decline) and the generic problems firms go through during growth. Indeed, stage models show that there are certain problems associated with each stage of business growth and these problems are unique at each stage of firm development (Olson, 1987; Kazanjian, 1988; Walsh, 1988; Moy and Luk, 2003). Accordingly, O'Gorman (2001) indicated that it is important to overcome obstacles at each stage so that small businesses can move through different stages in order to achieve growth. However, recent empirical work (Delmar, Davidsson and Gartner, 2003) suggests that research must focus on the heterogeneous patterns of growth outcomes. In this case, the primary motives of the entrepreneurs tend to be mediated by different factors leading to numerous growth paths.

Of the models discussed so far, the work of Hanks et al., (1993) appears to be most suitable for explaining business growth. The reason is that, the model provides evidence to suggest that with reference to increasing age and size, there is a sequential progression of organizations through the stages in the evolvement and development of enterprises. Similar assumption has been raised by Kazanjian and Drazin (1989); suggesting that there is a sequential progression of enterprises through stages as they evolve. Although, Hanks et al., 
(1993) suggested some limitations such as being based on one particular industry and geographic setting, their study represents is one of the most significant attempts in elucidating research-based stage models.

\section{Modes of business growth}

Small businesses grow in a number of ways including internal organic growth (e.g. organic and acquisitions) and external growth (e.g. internationalisation or multiple locations). Entrepreneurs are likely to embark on different forms of growth based on their wider motivations (Delmar, Davidsson and Gartner, 2003). For example, entrepreneurs of acquired businesses are more likely to embark on high growth than owners of independent businesses. In the sections that follow next, modes of growth of small business are discussed.

\section{Organic growth vs acquisitions}

Growth through acquisitions depicts a strategy in which a firm buys another firm or business (Park and Jank, 2010). In her seminal work, Penrose (1959) stressed the existence of different routes to growth, notably organic growth versus growth by acquisitions. She highlighted that organic growth can be limited by three factors: internal factors (e.g. managerial ability), external factors (e.g. product or factor markets) and a combination of internal and external factors (e.g., risk or uncertainty).

Indeed, regarding individual and strategy related factors, organic growth does not take place automatically, but depends on growth opportunities in the market and specialised resources and managerial abilities in order to plan and allocate the resources efficiently (Penrose, 1959). For example, businesses that want to grow organically may embark on specialised technological training that can enhance the day-to-day operational strength of the companies. The new skills acquired by the employees can provide additional value to the existing operational capacity of the business which in turn allows the business to grow its market. It 
has been argued by a number of scholars (e.g., Davidsson, Achtenhagen and Naldi, 2010) that this experience and knowledge will remain unused if the business fails to grow further.

Indeed, Penrose (1959) espoused several arguments for explaining why firms might decide to acquire existing firms for growth. When entering new markets, the costs as well as managerial and technical difficulties could be reduced by acquiring another firm. Thus, using acquisition strategy small businesses are likely to overcome market deficiencies and achieve faster growth. Accordingly, Penrose (1959:129) highlighted that "thus the existing resources of a firm will not limit the extent to which successful expansion can be effected through acquisition, but will also influence the direction of external expansion',

Research evidence suggests that motives behind acquisitions include market-access, expansion; diversification; sustainable competitive advantage; response to revolutionary change in the industry; and/or acquisition of knowledge of other businesses, firms and industries (UNCTAD, 2000; Deiser, 1994; von Krogh et al., 1994; Kruger and MullerStewens, 1994; Lockett et al., 2011). Acquisitions can be defensive strategy aimed at protecting market share in a declining or consolidating industry. The rationale behind acquiring another business may be to help the acquirer attain its strategic goals more quickly and inexpensively than if the company acted on its own. Such moves may help the small business to overcome barriers associated with competition and market deficiencies.

Research on the effects of acquisitions on business growth has produced mixed results. Whiles several scholars have reported a negative relationship between acquisitions and business growth (e.g., Mueller, 1985; Odagiri and Hase, 1989; Cosh et al., 1989), other scholars have reported a strong positive relationship between the two concepts (Taketoshi, 1984). However, acquisitions are advantageous because the results of acquisitions are likely to be seen quickly than internal growth (Park and Jang, 2010). 
According to Penrose (1959) growth through acquisitions enables the business to acquire tangible and intangible assets. This may help alleviate managerial constraints leading the growth of the business. Further, Marks and Mirvis (2001) argued that the outcomes of acquisitions allow businesses to gain flexibility, leverage competencies, share resources, and create opportunities that otherwise would be impossible.

\section{Growth through networks and alliances}

Research on networks has a long standing history in the management and organisational theory literature (Lechner, Dowling and Welpe, 2006) as well as discussion of entrepreneurs' personal network (e.g., Birley, 1985) and firm networks (e.g., Butler and Hansen, 1991). Network theory offers important understanding into how businesses relate to each other and grow. Indeed, several researchers have developed typologies of networks (e.g., Knoke and Kuklinsky, 1983; Aldrich and Zimmer, 1986; Melin, 1987; Johannisson, 1987; Uzzi, 1997; Lechner, Dowling and Welpe, 2006). Further, a number of empirical studies have indicated that networks lead to business growth (Donckels and Lambrecht, 1995; Hansen, 1995). For example, research in the field of economic sociology (Grabher and Stark, 1997b).

According to Yli-Renko, Autio and Sapienza (2001) through external linkages entrepreneurs acquire knowledge, especially in the knowledge intensive industry. It has also been argued that alliances provide the platform for a collective learning process in which ideas related to business development are exchanged and further developed as well as giving the opportunity for knowledge sharing among individual businesses (Kale et al., 2000; Hardy, Philips and Lawrence, 2003).

Moreover, research evidence indicates that small business managers continuously learn from other small business counterparts instead of the formal classroom learning process (Kitching, 
2008). Indeed, a number of scholars have explicitly converged on the above notion, suggesting that licensing, alliances and joint ventures are important for high growth firms (e.g., Killing, 1978; Roberts and Berry, 1985; Blundel, 2002; Street and Cameron, 2007; Watson, 2007). Thus, the evidence points to the role of networks and alliances in enhancing business growth.

\section{Growth through internationalization}

Growth through internationalization is perhaps the most complex strategy that any business can opt for in the quest to grow. However, internationalisation strategy may be adopted by entrepreneurs to counter the local market inefficiencies and barriers in the local business environment. The expansion of small businesses is viewed as an entrepreneurial act because it involves the setting-up of product markets (Thorelli, 1987; Ibeh, 2003). A large body of literature exists on the internationalisation process of small businesses (Andersen, 1993; Leonidou and Katsikeas, 1996). According to Westhead, Wright and Ucbasaran (2001) the way to understand internationalisation was a consequence of the resources that the firm held.

Much of the early empirical evidence on internationalization behaviours has concluded that the route to internationalisation involves a series of incremental 'stages' with exporting as an initial route to internationalisation. In this regard, internationalization can be seen as a part of a firm's growth and development strategy as it is involved in cross-border and market related activities (Jones, 1999). This resonates with Penrose's (1959: 1) fundamental meaning of growth who argued that "an increase in size or an improvement in quality as a result of a process'”

Indeed, growth through internationalisation which centres on exporting, foreign direct investment (FDI) and alliances has been recognised as a strategy for enhancing performance of high growth firms (Lu and Beamish, 2001). Small businesses that enter new geographical 
markets may have the opportunity to expand their customer base. Further, internationalisation may lead to increase in revenue that can provide the possibility of an increased production volume and increased production capabilities of the firm to fulfil the demands of its customers (Lu and Beamish, 2001). Engaging in exporting allows businesses to commit greater resources to foreign markets and focus on countries that are "physically" distant (Bell, Crick and Young, 2004).

In his seminal work, Ansoff (1965) developed a product-market matrix that identifies new market development, also referred to as internationalisation as a forward looking strategy for fast small business growth. Accordingly, small business may regard international market as secondly to the domestic market activities. Thus, domestic markets and international markets are often viewed as divergent strategic options rather than complementary strategies for growth (Bell, Crick and Young, 2004). Resource constraints may also stop small firms from entering the international market (Carson et al., 1995).

Though internationalization may be the riskiest business growth strategy, entrepreneurs may use this strategy as a reaction to market constraints in the domestic market. Small businesses may adopt the internationalization as strategy to minimize risk in the business environment. Thus, for small businesses to minimize the variations in sales and profits, firms enter international markets to take advantage of business cycle differences among countries. Some scholars have argued that small firms export because they have a unique product and a technological edge over competitors (e.g., Pope, 2002). Small businesses might also use the internationalisation strategy as a defensive strategy to fight rivals in the international market rather than in the home market.

Interestingly, research on internationalisation as a route to growth acknowledges that the process of growth not always unidirectional (Davidsson, Achtenhagen and Naldi, 2010). 
Rather, scholarly studies directs out attention to how businesses reduce their international activities or withdraw from international operations (Benito and Welch, 1997). Indeed, research on international growth of new and small businesses has so far not yielded many strong generalizations (Davidsson, Achtenhagen and Naldi, 2005). Thus, internationalisation as route to growth provides a fresh area for future scholarly work.

\section{Determinants of business growth}

The issue of whether business growth is determined internally, externally or both remains to a large extent unanswered question in the literature. The extant literature that classifies external and internal factors that influence small business growth has categorised them in different ways. For example, some previous studies have differentiated between the individual and environmental variables that influence small business growth (Ronstadt, 1984; Bygrave, 1994). Storey (1994) categorised variables that affect small business growth under three broad headings namely: the entrepreneur, characteristics of firm and strategy of the firm. Storey (1994) indicated that these categorisations are based on starting resources of the entrepreneur, characteristics of the business and the strategy developed by the business. The Table 2 below depicts Storey's (1994) classification of factors that affect business growth.

Table 1: Storey's (1994) Variables Influencing Small Business Growth

\begin{tabular}{lll}
\hline Entrepreneur & Firm & Strategy \\
\hline Motivation & Age & Workforce Training \\
Unemployment & Sector & Management training \\
Education & Legal form & External Training \\
Management Experience & Location & External Equity \\
Number of Founders & Size & Technology \\
Prior self-employment & Ownership & Market positioning \\
Family History & & Market Adjustments \\
Social marginality & & Planning \\
Functional Skills & & State Support \\
Training & & New products \\
Age & & Management Recruitment \\
Prior Business failure & & Customer Concentration \\
Prior Sector Experience & & Competition \\
Prior Firm size Experience & & Information and advice
\end{tabular}


Source: Storey (1994)

Storey (1994) identified key variables to each component and advanced the importance of combining all the components appropriately for rapid growth to take place. Each component provides a unique offering; the entrepreneur can be recognised prior to start-up, the business manifests decisions made on start-up while strategy reflects its growth rate. However, exact prediction is vital to the entrepreneur than historical accounts. Storey's (1994) mechanistic approach contributes little to provide the chemistry that puts together these perspectives for growth to occur. The issue here is to determine whether internal influences such as ownermanagers' growth aspirations matter or whether external variables matter in determining small business growth. Moreover, Storey's (1994) variables are all individually and empirically derived variables that have consistent impact on growth but there is no suggestion of which combination of factors is important.

Similarly, several studies have reported high growth in businesses with a variety of size and age characteristics (Smallbone and North, 1995; Rutherford et al., 2001). Thus, the evidence provides solid grounds to argue that younger businesses are not likely to grow more than older businesses. For this reason older businesses' potential to grow should not be ignored.

Indeed, a complex array of external variables that influence small business growth as suggested by the population ecology perspective (Hannan and Freeman, 1977) could be located around the structure of industries and markets. Previous research indicates that there is a rapid growth of businesses in dynamic industries and regions (Davidsson and Delmer, 1997; Carroll and Hannan, 2000). Thus, there is a convincing evidence to suggest that business growth is externally determined to some extent. Conversely, there is a compelling evidence to argue that owner-managers' growth aspirations or willingness to grow, their 
growth motivation and communicated vision influence business growth (Kolvereid and Bullvag, 1996; Baum, Locke \& Smith, 2001; Delmer and Wiklund, 2003).

A review of the literature suggests that growth is to some extent an issue of willingness and skill, but basic enablers and constraints in the environment cannot be ignored. Thus, prevailing scholarly studies have concluded that business growth is influence by many factors including the management strategies, characteristics of the entrepreneur, environment/industry specific factors and characteristics of the business (Dobbs and Hamilton, 2007; Smallbone and Wyner, 2000). However, this classification is not new as many of the elements in this classification have been professed in previous studies (Storey 1994; Smallbone and North, 1995; Barkham et al., 1996; Baum, Locke and Smith, 2001; Delmar, Davidsson and Gartner, 2003; Wiklund and Shepherd 2003; Edelman et al., 2005; Smallbone and Wyer 2006; Street and Cameron, 2007). However, a major conclusion that can be derived from prevailing scholarly reviews is that business growth is influenced by a mirage of internal and external factors.

A wide array of internal factors that affect business growth has been cited in the entrepreneurship literature. For example internal factors include factors related to firm strategy (Olson and Bokor, 1995; Bamford, Dean and McDougall, 1997; McMahon, 1998; Freel and Robson, 2004; Wiklund and Shepherd, 2005), factors related to the characteristics of the entrepreneur (e.g., Davidsson, 1989a; Storey, 1994; Smallbone and Wyer, 2000; Barringer and Jones, 2004) and characteristics of the business. The characteristics of the business relate to key decisions made on starting the business which are deemed to impact on growth of the business. Extant literature shows that firm age and size, legal status, sector affiliation and firm location all relate to growth (Storey, 1994). Significantly, the discussion of age and size as drivers of business growth has long been examined in the literature 
following the formulation of 'Gibrat's Law' (Gibrat, 1931). According to the Gibrat's law, the rate of growth of a firm is independent of its size at the beginning of the period and that the probability of a given growth rate during specific time interval is the same for any business within the same industry. However, the growth influences of age on business growth are mixed (Davidsson, Achetenhagen and Wiklund, 2010).

With regards to external factors that drive business growth, the population ecology perspective (Hannan and Freeman, 1977) suggests that external environmental forces affect a firm's growth. Indeed, several other studies indicate that the external business environment influences success of businesses (Dess and Beard, 1984; Kangasharju, 2000; Hawawini, Subramanian and Verdin, 2003).

\section{Constraints to growth}

In the small business literature, constraints are frequently part of studies on characteristics of business growth (e.g., Kazanjian, 1988; Pissarides, Singer and Svejnar, 2003). Additionally, constraints have been used to distinguish between firms which are likely to grow or not (Aidis, 2005; Robson and Obeng, 2008). The concept of barriers tends to be growth deterrent (Davidsson et al., 2004; Doern, 2009). Accordingly, research has documented the existence of such constraints in the entrepreneurship and small business literature where scholars have differentiated between 'internal' (e.g. lack of managerial/technical know-how, vision, capacity, finance) and 'external' constraints (e.g. adverse market conditions, economic/institutional arrangements) (Robson and Obeng 2008; Allinson et al., 2013). However, the idea of 'internal' constraints seems to concern the knowledge and ability of the small business managers which seems closer to concepts of the knowledgeable agent (Giddens, 1984), whereas external constraints go beyond individuals (Mole and Mole, 2010). 


\section{Finance barriers}

Finance barriers constitute one of the main barriers that hinder business growth. The entrepreneurship literature suggests that there is a general consensus that access to finance is a major problem to entrepreneurship (Keyser et al., 2000; Sciffer and Wede, 2001; Moy and Luk; 2003; Tagoe et al., 2005; Robson and Obeng, 2008). The main issue for most entrepreneurs is whether to go for equity financing and dilute ownership or rely on debt financing or internal financing. This has spurred two streams of research on financial barriers. These are (i) external barriers which are mostly related to the supply of finance and (ii) internal barriers which are related to demand for finance. The barriers connected to the supply of finance include difficulty in accessing capital and high cost of capital. The difficulty in accessing capital has been attributed to factors such as attitudes of lenders or to information gap between suppliers of money and small business owners (Binks \& Ennew, 1996). On the demand-side of the argument, most entrepreneurs believe that accessing finance from external source dilute ownership. The unwillingness of owner-managers of small businesses to relinquish power to external parties serves as a constraint to small business growth (Storey, 1994; Burns, 2001).

\section{Managerial and technical know-how}

Managerial and technical know-how are considered valuable assets to small businesses because it is not possible to take away knowledge from individuals as tangible and financial assets can be taken (Barney, 1991; Becker, 1975; Chandler and Jansen, 1992; Cooper et al., 1994). Lack of skilled managers and absence of business skills in marketing and business development contribute to the problems of small business growth (Bartlett and Bukvic, 2001; Robson and Obeng, 2008). Small businesses may find it difficult to attract skilled employees, train and retain them. Because small businesses are unable to attract skilled labour due to high wages and other factors, the focus on training becomes relevant in small businesses. The 
evidence on the relationship between training and performance are conflicting. Whiles some studies have failed to place a link between training and improved performance (Storey \& Westhead, 1997), other studies (Cosh et al., 2000; Mano et al., 2012) support the view that training could lead to improved performance. Yet, small businesses' investment in training has not been encouraging. The reason may be that entrepreneurs fear of losing trained employees to larger organisations that offer high remuneration and better conditions of services. It can also be attributed to the fact that smaller businesses do not have a strong financial muscle to invest in training (Carter et al., 2006). This suggest that financial backing in the form of funding is needed in small businesses to allow them undertake training for their staff.

\section{Regulatory and economic constraints}

Previous empirical studies on institutions and regulatory barriers tend to examine the kinds of institutions that hamper businesses business growth (Baumol, 1990; Bartlett and Bukvic, 2001; Krasniqi, 2007; Roxas et al., 2007). Some government's institutions and regulatory policies have equally been identified as a source of constraint to small business growth. Certain institutions pose burden on small business and may discourage entrepreneurial activities (Davidsson and Henreksson, 2002; Carter et al., 2006; Smallbone and Welter, 2001b). Legislations which demand the preparation and delivery of documents where expert assistance will be needed, creates compliance costs which will probably pose a greater burden for $\mathrm{SME}_{S}$, since they do not usually have such resources on their payroll (Smallbone and Welter, 2001b).

The focus on regulatory and institutional barriers has been that regulatory and institutions barriers influence decisions and actions of businesses (Aldrich and Fiol, 1994). However, the literature is silent on how regulations and institutions affect small business decisions and 
actions (Peng and Heath, 1996). While there appears to be an agreement on what constitutes a negative environment, little is known about what constitutes a positive environment.

\section{Market constraints}

The market environment in which the business operates is associated with certain barriers that hamper its growth. These constraints include those that reflect the market structures and competitors' behavior (ACOST, 1990) and other factors such as cost of advertising and market research obstacles (Robson and Obeng, 2008). Factors such as low demand for products/services, exporting difficulties, highly competitive environment can hinder the growth of small businesses. Market constraints can be approached in two ways: external barriers and internal barriers. External barriers vary depending upon the extent of market competition and the sector in which the business operates (Bartlett and Bukvic, 2001). Several studies have revealed that competition or market challenges adversely affect small business growth (e.g., Kazanjian, 1988; Hay and Khamshad, 1994; Moy and Luk, 2003, Gill and Biger, 2012).

Internal market barriers on the other hand, involve identification of market opportunities (Davidsson, 2004), choosing a market segment (McGee, 1989) and the business' weakness in extending resources and opportunities to the market segment (ACOST, 1990). Business opportunity is created when the firm's market, services and product are expanded. In a recent study, Robson and Obeng (2008) reported that smaller businesses are likely to encounter inadequate demand than larger businesses.

\section{Discussion and Conclusion}

This review has examined the phenomenon of business growth including definition of small business growth, ways of measuring growth, theories business growth, drivers and constraints to growth. The review suggests that models of business growth have been portrayed in a 
fragmented and inconsistent manner (Weinzimmer et al., 1998) and that growth is now regarded as an episode rather a classification of firm. We note that there is lack of consensus regarding which model is appropriate in addressing business growth. Furthermore, existing studies have explicitly failed to define growth models and no effort has been made to distinguish between life-cycle, growth stages or development stages (Hanks et al., 1993). Moreover, our review suggests that stage models of growth only depict symptoms of growth and do not reflect the underlying causes of growth.

We note that business growth measurement has mixed and inconsistent. However, the two most common ways of measuring business growth are sales and employment. It is important to acknowledge that notwithstanding this notion of growth conceptualization, other scholars equate growth with 'mere' increase in volume (e.g., Davidsson and Wiklund, 2000; Delmar, Davidsson and Gartner, 2003, Delmar et al., 2003; Barringer et al., 2005; Delmar and Wiklund, 2008; Shepherd and Wiklund, 2009). We note that several studies use multiple measures to examine business. The evidence suggests that notwithstanding the several advantages associated with the use of multiple indicators, such as sales and employment, a major shortcoming of the use of multiple indicators is that the assumption of common cause may be incorrect (Delmar, Davidsson and Gartner, 2003). Further, some scholars are of the view that different growth measures and calculations of business growth influence model building and theory development differently and advocate for the use of a single measure of business growth (Chandler and Hanks, 1993; Delmar, 1997; Weinzimmer et al., 1998).

Regarding modes of growth, robust evidence suggests organic vs. acquisition growth, growth though networks and alliances, and growth through internationalization. The literature suggests that business owner embark on different forms of growth based on their wider motivations (Delmar, Davidsson and Gartner, 2003). We know little about which mode of 
growth is much more efficacious in driving business growth. To date, studies have generally ignored the mode of growth which best spurs business growth. As a result, our understanding regarding which mode achieves business growth best is constrained and possibly takes an overly simplistic view of this phenomenon.

With specific regards to factors that drive business growth, the extant literature has classified external and internal factors. Yet the issue of whether business growth is determined internally, externally or both remains to a large extent unanswered question in the literature. Therefore, future studies may examine the extent to which business growth is determined internally, externally or both. It should, however, be acknowledged that it is sometimes difficult to determined what factors are truly 'external, and 'internal' (e.g., Davidsson, 1989a; 1991; Chandler and Hanks, 1994).

Lastly, the literature suggests that some factors influence business as growth deterrents (Davidsson, 1989b) which have negative influence on business growth (Barber, Metcalfe and Porteous, 1989). Accordingly, constraints have been used to distinguish between firms which are likely to grow or not (Aidis, 2005, Robson and Obeng, 2008). However, research on constraints to business growth limits our understanding on how entrepreneurs deal with or react to constraints to growth by "writing individuals out of the story" (Jennings, Perren and Carter, 2005: 147). Such treatment of constraints gives an incomplete picture of the role entrepreneurs in dealing with constraints. We suggest that there exist a significant opportunity for understanding how entrepreneurs react to business constraints. Such an understanding holds potential for policy and practical interventions to mitigate constraints in business growth process. Therefore, future research should focus on how entrepreneurs react to constraints to growth. 


\section{References}

Achtenhagen, L., Naldi, L \& Melin, L. (2010). Business growth-do practitioners and scholars really talk about the same thing? Entrepreneurship Theory and Practice, 34: 289316.

ACOST. (1990). The enterprise challenge: Overcoming barriers to growth in small firms. The Advisory Council on Science and Technology, UK. London: HMSO

Aidis, R. (2005). Institutional barriers to small-and medium-sized enterprise operations in transition countries. Small business economics, 25, 305-317.

Adizes, I. (1989). Corporate Lifecycles: How and Why Corporations Grow and Die and What to Do About It, Prentice-Hall, Englewood Cliffs, New Jersey.

Aldrich, H. E., \& Fiol, M. C. (1994). Fools rush in? The institutional context of industry creation. Academy of Management Review, 19: 645-670.

Aldrich, H.W \& Zimmer, C. (1986). Entrepreneurship through social networks. In: Sexton, D., Smilor, R. (Eds.), The art and science of entrepreneurship. Ballinger, Cambridge, MA, 3-23.

Allinson, G., Braidford, P., Houston, M., \& Stone, I. (2013). Understanding growth in microbusinesses: . London: BIS Research paper Number 114.

Allinson, G., Braidford, P., Houston, M. \& Stone, I. (2006). Myths Surrounding growing a business small business Service, http://www.sbs.gov.uk/SBS_Gov_files/researchandstats/MythsSurroundingGrowing ABusiness2006.pdf

Andersen, O. (1993). On the Internationalization Process of Firms: A Critical Analysis', Journal of International Business Studies, 24(2): 209-31.

Anderson, B. S \& Eshima, Y. (2013). The influence of firm age and intangible resources on the relationship between entrepreneurial orientation and firm growth among Japanese SMEs. Journal of Business Venturing, 28 (3): 413-429

Ansoff, H. I. (1965). Corporate strategy, McGraw-Hill, New York,

Ardishvili, A., Cardozo, S., Harmon, S. \& Vadakath, S. (1998). Towards a theory of new venture growth. Paper presented at the 1998 Babson Entrepreneurship Research Conference, Ghent, Belgium

Arregle, J.L., Batjargal, B., Hitt, M.A., Webb, J.W., Miller, T., and Tsui, A.S.(2013). Family ties in entrepreneurs' social networks and new venture growth. Entrepreneurship Theory and Practice 39: 313-344. doi: 10.1111/etap.12044

Bamford, C. E., Dean, T. J., \& McDougall, P. P. (1997). Initial strategies and new venture growth: An examination of the effectiveness of broad vs. narrow breadth strategies. In P. D. Reynolds, W. D. Bygrave, N. M. Carter, P. Davidsson, W. B. Gartner, C. M. Mason, \& P. P. McDougall (Eds.), Frontiers of Entrepreneurship Research (pp. 375-389). Wellesley, MA: Babson College.

Becchetti, L \& Trovato, G (2002). The determinants of growth for small and medium sized firms. The role of the availability of external finance, Small Business Economics, 19 (4): 292-306

Barber, J., Metcalfe, J. S. \& Porteous, M. (1989). Barriers to Growth in Small Firms. London: Routledge.

Barkham, R., Gudgin, G., Hart, M. \& Hanvey, E. (1996). The determinants of small firm growth: an inter-regional study in the United Kingdom 1986-1990, London: Jessica Kingsley Publishers.

Barney, J. (1991). Firm resources and sustained competitive advantage, Journal of 
Barringer, B. R., Jones, Foard, F., \& Neubaum, \& Donald, O. (2005). A quantitative content analysis of the characteristics of rapid growth firms and their founders, Journal of Business Venturing, 20(5): 663-687.

Barringer, B.R. \& Jones, F.F. (2004). Achieving rapid growth - revisiting the managerial capacity problem, Journal of Developmental Entrepreneurship, 9(1): 73-87.

Bartlett, W \& Bukvič, B (2001). Barriers to SME growth in Slovenia, Economic Policy in Transition Economies, 11(2): 177-95.

Baum, J. R., Locke, E. A. \& Smith, K. G. (2001). A multidimensional model of venture growth. Academy of Management Journal, 44(2): 292-303.

Baumol, W. (1990). Entrepreneurship: Productive, unproductive and destructive, in Journal of Political Economy, 98: 893-921

Beck. T., Lu., L \&Yang, R. (2015). Finance and Growth for Microenterprises: Evidence from Rural China. World Development, 67: 38-56

Becker, (1975). Human Capital. Chicago, IL: Chicago University Press.

Bell, J., Crick, D \& Young, S. (2004). Small firm internationalisation and business strategy: an exploratory study of 'knowledge-intensive' and 'traditional manufacturing firms in the UK, International Small Business Journal, 22(1): 23-56

Benito, G. R. G. \& Welch, L. S. (1997). De-internationalisation. Management International Review, 37 (2): 7-25.

Binks, M.R. \& Ennew, C.T. (1996).Financing small firms, in Burns, P. and Dewhurst, J. (Eds.), Small Business and Entrepreneurship, 2nd ed., Macmillan, London.

Birley, S. (1985). The role of networks in the entrepreneurial process. Journal of Business Venturing, 3(1): 107-117

Birley, S., \& Westhead, P. (1990). Growth and performance contrasts between "types" of small business. Strategic Management Journal, 11 (7): 535-557.

Blundel, R. (2002). Network evolution and the growth of artisanal firms: a tale of two regional cheese makers. Entrepreneurship \& Regional Development, 14(10): 1-30

Burns, P. (2001) Entrepreneurship and Small Business. Basingstoke: Palgrave.

Butler, J. E. \& Hansen, G. S. (1991). Network evolution, entrepreneurial success, and regional development. Entrepreneurship and Regional Development, 3(1): 1-16.

Bygrave, W.D. (1994), The Portable MBA in Entrepreneurship. Chichester: John Wiley

Capasso, M., Treibich, T \& Verspagen, B. (2015). The medium-term effect of R\&D on firm growth, Small Business Economics, 45:39-62

Carpenter, R. E., \& Petersen, B.C. (2002). Capital market imperfections, high-tech investment, and new equity financing, The Economic Journal, 112: 54-F72.

Carroll, G. R. \& Hannan, M. T. (2000). The demography of corporations and industries.

Princeton, NJ: Princeton University Press.

Carter, S. \& D. Jones-Evans. (2006). Enterprise and Small Business. Harlow: FT PrenticeHall.

Carson, D., Cromie, S., McGowan, P. and Hill, J. (1995) Marketing and Entrepreneurship in SMEs: An Innovative Approach. London: Prentice Hall.

Chandler, G.N.\& Baueus, D.A. (1996). Gauging performance in emerging businesses: longitudinal evidence and growth patterns analysis, in Reynolds, P.D. et al. (Eds), Frontiers of Entrepreneurship Research, Center for Entrepreneurial Studies, Babson College, Babson Park, MA

Chandler, G. N., \& Hanks, S. H. (1993). Measuring the performance of emerging businesses: A validation study. Journal of Business Venturing, 8: 391-408

Chandler, G.N. \& Jansen, E. (1992). The founder's self-assessed competence and 
venture performance. Journal of Business Venturing. 7(3): 223-236.

Chandler, G.N., McKelvie, A., \& Davidsson, P. (2009). Asset specificity and behavioural uncertainty as moderated of the sales growth-employment relationship in emerging ventures. Journal of Business Venturing, 24: 373-387

Chrisman, J. J., \& Leslie. J. (1989). Strategic, administrative, and operating problems: the impact of outsiders on small firm performance. Entrepreneurship Theory \& Practice, 13(3): 37-51.

Coad, A. (2007). Firm growth: A survey, CES Working Papers 2007.24, University Sorbonne, Paris.

Coad, A., Segarra, A., \& Teruel, M. (2016). Innovation and firm growth: Does firm age play a role?. Research Policy, 45(2), 387-400.

Cooper, A. C., Gimeno-Gascon, F. J., \& Woo, C. Y. (1994). Initial Human and Financial Capital as Predictors of New Venture Performance. Journal of Business Venturing, 9(5), 371-395.

Cosh, A.D., Hughes, A \& Lee., K. (1989). Institutional investment, mergers and the market for corporate control. International Journal of Industrial Organisation, 7(1):73-100

Davidsson, P. (1989a). Continued Entrepreneurship and small Firm growth. Stockholm:

Stockholm School of Economics

Davidsson, P. (1989b). Entrepreneurship -- and after? A study of growth willingness in small firms. Journal of Business Venturing, 4(3), 211-226.

Davidsson, P. (1991). Continued entrepreneurship: Ability, need, and opportunity as determinants of small firm growth. Journal of Business Venturing, 6 (6): 405-429.

Davidsson, P. (2004). Researching entrepreneurship, New York: Springer.

Davidsson, P., Achtenhagen, L. \& Naldi, L. (2010). Small firm growth. Foundations and Trends in Entrepreneurship, 6(2): 69-166

Davidsson, P., Achtenhagen, L. \& Naldi, L. (2005). Research on Small Firms: A Review, Proceedings of the European Institute of Small Growth Business. Availablehttp://eprints.qut.edu.au/archive/00002072/01/EISB_version_Research_on _small_firm_growth.pdf Accessed 23/07/2013

Davidsson, P. \& Delmar, F. (1997). High-growth firms and their contribution to employment: The case of Sweden 1987-96. Paris: OECD Working Party on SMEs.

Davidsson, P \& Wiklund, J. (2000). Conceptual and empirical challenges in the study of frim growth. In D. Sexton \& H. Lnastrom (Eds.), Handbook of entrepreneurship. Oxford: Blackwell Publishers

Davidsson, P. \& Wiklund, J. (1999). Theoretical and Methodological Issues in the Study of Firm Growth. Jönköping International Business School, Working Paper Series: 99-6

Davidsson, P. \& Henkerson, M. (2002). Determinants of the prevalence of start-ups and highgrowth firms, Small Business Economics, 19(2): 81-100.

Davidsson, P., Steffens, P. \& Fitzsimmons, J. (2009). Growing profitable or growing from profits: Putting the horse in front of the cart? Journal of Business Venturing, 24: 388-406

Deiser, R. (1994). Post-acquisition management: a process of strategic and organizational learning. In von Krogh, G., Sinatra, A. and Singh, H. (Eds). The Management of Corporate Acquisitions: International Perspectives. The Macmillan Press, London.

Delmar, F. (1997). Measuring growth: methodological considerations and empirical results. In R. Donckels \& A. Miettinen (Eds.), Entrepreneurship and SME Research: On its Way to the Next Millennium. Aldershot, UK and Brookfield, VA: Ashgate.

Delmar, F., (2000). Measuring Growth: Methodological Considerations and Empirical 
Results. Entrepreneurship and Small Business Research Institute (ESBRI), Stockholm

Delmar., F. Davidsson, P. \& Gartner, W. (2003). Arriving at the High-Growth Firm, Journal of Business Venturing, 18(2): 189-216.

Delmar, F. \& Wiklund, J. (2008). The Effect of Small Business Managers' Growth Motivation on Firm Growth: A Longitudinal Study, Entrepreneurship Theory and Practice, 32(3): 437-453.

Dess, G.G. \& Beard, D.W. (1984). Dimensions of organisational task environment.

Administrative Science Quarterly, 29:52-73.

Dess, G. G. \& Davis, P.S. (1984), 'Porter's (1980) Generic Strategies as Determinants of Strategic Group Membership and Organizational Performance', Academy of Management Journal, 27(3), pp. 467-488.

Dhanaraj, C., \& Beamish, P.W. (2003). A resource-based approach to the study of export performance. Journal of Small Business Management 41 (3): 242-261.

Didier, T \& Schmukler, S.L. (2013). The financing and growth of firms in China and India: Evidence from capital markets. Journal of International Money and Finance 39: $111-137$

Dobbs, M., \& Hamilton, R. T. 2007. Small business growth: recent evidence and new directions. International Journal of Entrepreneurial Behaviour and Research, 13(5): 296-322.

Donckels, R. \& Lambrecht , J. (1995). Networks and small business growth: An explanatory model. Small Business Economics,7 (4): 273-289.

Dodge, H.R. \& Robbins, J.E. (1992). An Empirical Investigation of the Organisational lifeCycle Model for small Business Development and survival, Journal of Small Business Management, 30(1): 27-34

Donaldson, L., (1987). Strategy and structural adjustment to regain fit and performance: In defence of contingency theory. Journal of Management Studies 24 (1): 1-24

Dunne, P \& Hughes, A. (1986). Age, size, growth and survival revisited. Working Paper No.23. Small Business Research Centre. University of Cambridge

Edelman, L. F., Brush, C. G., \& Manolova, T. (2005). Co-alignment in the resourceperformance relationship: strategy as mediator. Journal of Business Venturing, 20: 359-383.

Eisenhardt, K.M. (1989). Making fast strategic decisions in high-velocity environments. Academy of Management Journal, 32: 543-576.

Eisenhardt, K. M., \& Schoonhoven, C. B. (1990). Organizational growth: linking founding team, strategy, environment, and growth among US semiconductor ventures, 19781988. Administrative Science Quarterly, 35 (3): 504-529.

Fafchamps, M., McKenzie, D., Quinn, S \& Woodruff, C. (2014). Microenterprise growth and the flypaper effect: Evidence from a randomized experiment in Ghana, Journal of Development Economics 106: 211-226

Federico, J.S \& Capelleras, J.L. 2015. The heterogeneous dynamics between growth and profits: the case of young firms, Small Business Economics, 44:231-253

Flamholtz, E.G. (1986). Managing the transition from an entrepreneurship to a professionally managed firm. San Francisco: Jossey-Bass

Freel, M.S. \& Robson, P.J.A. (2004). Small firm innovation, growth and performance, International Small Business Journal, 22(6): 561-75.

Garcǐa-Posada, M \& Mora-Sanguinetti, J.S. (2014). Does (average) size matter? Court enforcement, business demography and firm growth, Small Business Economics, 44:639-669

Garnsey, E. (1998). A theory of the early growth of the firm. Industrial and Corporate 
Change 7: 523-556.

Gibb, A. A., \& Davis, L. (1990a). In pursuit of the frameworks of growth models of the small business. International Small Business Journal, 9(1): 15-31.

Gibrat, R. (1931). Les Inegalites Economiques, Librairie du Recueil Sirey, Paris.

Giddens, A. (1984). The Constitution of Society. Outline of the Theory of Structuration. Cambridge: Polity.

Gill, A \& Biger, N. (2012). Barriers to small business growth in Canada, Journal of Small Business and Enterprise Development, 19(4): 656 - 668

Gill, J. (1985). Factors affecting the survival and growth of the smaller company. Aldershot: Gower

Gilbert, B. A., McDougall, P. P., \& Audretsch, D. B. (2006). New venture growth: A review and extension. Journal of Management, 32(6): 926-950.

Glancey, K. (1998). Determinants of growth and profitability in small entrepreneurial firms, International Journal of Entrepreneurial Behaviour and Research, 4(1): 18-25.

Grabher, G \& Stark, D. (1997b). Organizing Diversity: Evolutionary Theory, Network Analysis, and Postsocialist Transformations. In G. Grabher \& D. Stark, eds. Restructuring Networks: Legacies, Linkages, and Localities in Postsocialism. Oxford University Press

Greiner, L.E. (1972). Evolution and revolution as organisations grow, Harvard Business Review, 50(4): 37-46.

Hamelin, A. (2013). Influence of family ownership on small business growth. Evidence from French SMEs, Small Business Economics (2013) 41:563-579 DOI 10.1007/s11187012 9452-x

Hamilton. R. T, \& Shergill, G, S. (1992). The relationship between strategy-structure fit and financial performance in New Zealand: Evidence of generality and validity with enhanced controls. Journal of Management Studies. 29: 95-113

Hannan, M. T. \& Freeman, J. H. (1977). The Population Ecology of Organizations. American Journal of Sociology, 82(5): 929-964.

Hanks, S.H. \& Chandler, G.N. (1992). The growth of emerging firms: a theoretical framework and research agenda', paper to the 7th Annual National Conference of the United States Association for Small Business and Entrepreneurship, Chicago, Illinois.

Hanks, S.H., Watson, C.J., Jansen, E. \& Chandler, G.N. (1993). Tightening the life-cycle construct: a taxonomic study of growth stage configurations in high-technology organizations, Entrepreneurship Theory and Practice, 18(2): 5-29.

Hanks, S.H. (1990a). An Empirical Examination of the Organization Life Cycle in High Technology Organizations, Doctor of Philosophy Dissertation, University of Utah, Salt Lake City, Utah.

Hanks, S.H. (1990b). The organization life cycle: integrating content and process, Journal of Small Business Strategy, 1(1): 1-13.

Hanks, S.H. \& Chandler, G. (1994). Patterns of functional specialization in emerging high tech firms, Journal of Small Business Management, 32(2): 23-36.

Hanks, S.H., Watson, C.J., Jansen, E. \& Chandler, G.N. (1993). Tightening the life-cycle construct: a taxonomic study of growth stage configurations in high-technology organizations, Entrepreneurship Theory and Practice, 18(2): 5-29.

Hanks, S.H., Watson, C.J. \& Jansen, E. (1991). Toward a configurational taxonomy of the organization life cycle', in G.E. Hills \& R.W. LaForge eds Research at the Marketing/Entrepreneurship Interface, University of Illinois Press, Chicago, Illinois.

Hansen, E. L. (1995). Entrepreneurial network and new organization growth.

Entrepreneurship Theory \& Practice, 19(4): 7-19 
Hardy, C., Phillips, N., \& Lawrence, T. B. (2003). Resources, Knowledge and Influence: The Organizational Effects of Interorganisational Collaboration. Journal of Management Studies, 40(2): 321-347.

Hawawini, G., Subramanian, V. and Verdin, P. (2003). Is Performance Driven By Industry Or Firm-Specific Factors? A New Look at the Evidence. Strategic Management Journal, 24: 1-16

Hay, M \& Kamshad, K. (1994). Small firm growth: intentions, implementation and barriers, Business Strategy Review, 5(3): 49-68

Hessels, J. \& Parker, S.C. (2013). Constraints, internationalization and growth: A crosscountry analysis of European SMEs. Journal of World Business, 48, 137-148.

Hoy, F., McDougall, P. P. \& Dsouza, D. E. (1992). Strategies and environments of high growth firms. In D. L. Sexton \& J. D. Kasarda (Eds.), The State of the Art of Entrepreneurship, Boston: PWS-Kent Publishing.

Ibeh, N. (2003). Toward a contingency framework of export entrepreneurship:

Conceptualisations and empirical evidence. Small Business Economics, 20(1), 49-68

Jennings, P. L., Perren, L., \& Carter, S. (2005). Guest editors' introduction: alternative perspectives on entrepreneurship research. Entrepreneurship Theory and Practice, 29(2): 145-152.

Johannisson, B. (1987). Anarchists and Organizers: Entrepreneurs in a Network Perspective, International Studies of Management and Organization, 17(1): 49-63.

Johnson, P., Conway, C. \& Kattuman, P. (1999). Small business growth in the short run, Small Business Economics, 12(2): 103-12.

Jones, M.V. (1999). The internalisation of small high-technology firms. Journal of International Marketing, 7(4): 15-41

Jovanovic, B. (1982). Selection and the Evolution of Industry. Econometrica 50(3): 649-670.

Kale, P,. Singh, H., \& Perlmutter, H. (2000). Learning and protection of proprietary assets in strategic alliances: Building relational capital. Strategic Management Journal, 21: 217-37.

Kangasharju, A. (2000). Growth of the Smallest: determinants of small firm growth during strong Economic Fluctuations. International Small Business Journal, 19(1): 28-43

Kazanjian, R.K. (1988). Relation of dominant problems to stages of growth in technologybased new ventures, Academy of Management Journal, 31(2): 257-79.

Kazanjian, R.K. \& Drazin, R. (1989). An empirical test of stage of growth progression model, Management Science, 35(12): 1489-1503.

Kazanjian, R.K. \& Drazin, R. (1990). A stage-contingent model of design and growth for technology based ventures, Journal of Business Venturing, vol. 5(3): 137-150.

Kelley, D.J. \& Nakosteen, R.A. (2005). Technology resources, alliances, and sustained growth in new, technology-based firms, IEEE Transactions on Engineering Management, 52(3): 292-300.

Keyser, M., de Kruif, M., \& Frese, M. (2000). The Psychological strategy process and sociodemographic variables as predictors of success for micro-and small-scale business owners in Zambia. In M. Frese (Ed.), Success and failure of micro business owners in Africa: A psychological approach (pp. 31-54). Westport, CT: Quorum Books.

Killing, J. P. (1978). Diversification through licensing. R\&D Management, 8(3): 159-163.

Kimberly, J.R. \& Miles, R.H. (1980). 'Preface', in J.R. Kimberly, R.H. Miles \& Associates eds The Organizational Life Cycle: Issues in the Creation, Transformation, and Decline of Organizations, Jossey-Bass, San Francisco, California, pp. ix-xiii.

Kitching, J. (2008). Rethinking UK small employers' skills policies and the role of workplace 
learning. International Journal of Training and Development, 12(2): 100-120.

Kolvereid, L. \& Bullvåg, E. (1996). Growth intentions and actual growth: The impact of entrepreneurial choice. Journal of Enterprising Culture, 4(1): 1-17.

Knoke, D \& Kuklinski, J.H. (1983). Network Analysis. Beverly Hills: Sage Publications. Krasniqi, B. (2007). Barriers to entrepreneurship and SME growth in transition: evidence from Kosova, Journal of Developmental Entrepreneurship, 12(1): 71-94.

Kruger, W. \& Muller-Stewens, G. (1994). Matching acquisition policy and integration style, in von Krogh, G., Sinatra, A. and Singh, H. (Eds), The Management of Corporate Acquisitions: International Perspectives. London: The Macmillan Press.

LeBrasseur, R., Zanibbi, L. and Zinger, T.J. (2003). Growth momentum in early stages of small business start-ups, International Small Business Journal, 21(3): 315-30.

Lechner, C., Dowling, M. \& Welpe, I. (2006). Firm networks and firm development: The role of the relational mix, Journal of Business Venturing, 21: 514-540.

Leonidou, L. C. \& Katsikeas, C. S. (1996).The Export Development Process: An

Integrative Review of Empirical Models, Journal of International Business Studies

27(3): 517-51.

Littunen, H. \& Tohmo, T. (2003). The high growth firm in new metal-based manufacturing and business services in Finland, Small Business Economics, 21(2):187-200.

Locke, S. (2004). ICT adoption and SME growth in New Zealand, Journal of American Academy of Business, 4(1/2): 93-102.

Lockett, A., Wiklund, J., Davidsson, P. \& Girma, S. (2011). Organic and acquisitive growth: Re-examining and extending the Penrose's Growth Theory, Journal of Management Studies 48: 48-74.

Lu, J.W \& Beamish, P.W. (2001). The internationalization and performance of SMEs. Strategic Management Journal, 22(6/7): 565-586

Macpherson A, \& Holt, R. (2007). Knowledge, learning and SME growth: a systematic review of the evidence. Research Policy 36(2):172-192.

Mahoney, J.T., \& Michael, S.C (2005). A Subjectivist Theory of Entrepreneurship. Handbook of Entrepreneurship. Boston: Springer.

Mai, Y. \& Zheng, Y. ( 2013). How On-the-Job Embeddedness Influences New Venture Creation and Growth. Journal of Small Business Management, 51: 508-524. doi: $10.1111 /$ jsbm.12000

Mano, Y., Iddrisu, A., Yoshino, Y \& Sonobe, T. (2012). How Can Micro and Small Enterprises in Sub-Saharan Africa Become More productive? The Impacts of Experimental Basic Managerial Training, World Development, 40 (3), 458-468.

Marks, M.L. \& Mirvis, P.H. (1998). Joining forces: making one plus one equal three in mergers, acquisitions, and alliances, Jossey-Bass Publishers, San Francisco.

Masakure, O., Henson, S \& Cranfield, J (2009). Performance of micro-enterprises in Ghana: a resource-based view, Journal of Small Business and Enterprise Development, 16: 466-484

McGee, J. (1989). Barriers to growth: The effects of market structure. In J. Barber, J. S. Metcalfe \& M. Porteous. Barriers to small business growth: 173-195. London: Routledge.

McKelvie, M \& Wilund, J. (2010). Advancing firm growth research: a focus on growth mode instead of growth rate, Entrepreneurship Theory and Practice, 34: 261-288

McMahon, R. G. P. (1998). Stage Models of SME Growth Reconsidered', Small Enterprise Research: The Journal of SEAANZ, 6(2): 20-35.

Melin, L. (1987). The field-of-force metaphor: A study in industrial change. International Studies of Management and Organization, 17(1): 24-33.

Miller, D.(1987). Strategy making and structure: analysis and implications for performance. 
Academy of Management Journal 30(1): 7-32.

Miller, D. and Friesen, P. (1983). Strategy-making and Environment: The Third Link', Strategic Management Journal 4: 221-235.

Miller, D \& Toulouse, J.M. (1986a). Chief executive personality and corporate strategy and structure in small firms. Management Science, 32: 1398-1409

Mole, K. F. \& Mole, M. (2010). Entrepreneurship as the Structuration of Individual and Opportunity: A Response using a Critical Realist Perspective. Comment on Sarason, Dean and Dillard. Journal of Business Venturing, 25, 230-237.

Morrison, A. J. \& Roth. K. (1992). A taxonomy of business-level strategies in global industries. Strategic Management Journal. 13: 399-418.

Moy, J. W., \& Luk, V. W. M. (2003). The life-cycle model as a framework for understanding barriers to SME growth in Hong Kong. Asia Pacific Business Review, 10(2): 199-220.

Mueller, D.C (1985). Mergers and market share. The review of Economics and Statistics, 67: $259-267$

Naldi, L., \& Davidsson, P. (2014). Entrepreneurial growth: The role of international knowledge acquisition as moderated by firm Age. Journal of Business Venturing, 29: 687-703

Nkomo, S. M. (1987). Human resource planning and organizational performance: An exploratory analysis. Strategic Management Journal. 8: 387-392.

North, D. \& Smallbone, D. (2000). The innovativeness and growth of rural SMEs during the 1990s, Regional Studies, 34(2): 145-57.

Obeng, B.A., Robson, P \& Haugh, H. (2014). Strategic entrepreneurship and small firm growth in Ghana. International Small Business Journal, 32(5): 501-524

O'Cass, A \& Sok, P. (2014). The role of intellectual resources, product innovation capability, reputational resources and marketing capability combinations in firm growth, International Small Business Journal 32(8) 996-1018, DOI: $10.1177 / 0266242613480225$

Odagiri, H \& Hase, T. (1989). Are mergers and acquisitions going to be popular in Japan too?: an empirical study. International Journal of Industrial Organisation, 7(1): 49-72

O'Farrell, P \& Hichens, D. (1988a). Alternative Theories of Small Firm growth: A critical Review, Environmental Planning, 20: 1365-1383

O'Gorman, C. (2001). The sustainability of growth in small and medium sized enterprises, International Journal of Entrepreneurship Behaviour \& Research, 7(2): 60-71.

Olson, P. D. (1987). Entrepreneurship and management. Journal of Small Business Management, 25(3): 7-13.

Olson, P.D. \& Bokor, D.W. (1995). Strategy process-content interaction: effects on growth performance in small start-up firms, Journal of Small Business Management, 33(1): 34-44.

Orser, B.J., Hogarth-Scott, S. \& Riding, A.L. (2000). Performance, firm size, and management problem solving, Journal of Small Business Management, 38(4): 4258.

Park, K \& Jang, S. (2010). Mergers and acquisitions and firm growth: investigating restaurant firms, Journal of Hospitality Management, 23(7): 141-149

Pena, I. (2002). Intellectual capital and business start-up success, Journal of Intellectual Capital, 3(2): 180-98.

Peng, M. W., \& Heath, P. (1996). The growth of the firm in planned economies in transition: Institutions, organizations, and strategic choice. Academy of Management Review, 21(2): 492-528. 
Penrose, E. T. (1995).The Theory of the Growth of the Firm, third edition, Oxford: Oxford University Press

Penrose, E. T. (1959). The Theory of the Growth of the Firm. Oxford: Oxford University Press.

Penrose, E.T. (1952). Biological analogies in the theory of the firm, American Economic Review, 42(5): 804-819.

Peters, M.P., \& Brush, C.G. (1996). Market information scanning activities and growth in new ventures: a comparison of service and manufacturing businesses. Journal of Business Research, 36: 81-89.

Pitelis, C (2009). Edith Penrose's: The Theory of the Growth of the Firm' Fifty Years Later. MPRA Paper No. 23180, Online at http://mpra.ub.uni muenchen.de/23180/. Access 20/06/2015

Pitelis, C., (2007). Edith Penrose and a learning-based perspective on the MNE and OLI1. Management International Review, 47: 207-235

Pope, R. A. (2002). Why small firms export: Another look, Journal of Small Business Management 40(1): 17-26

Rahaman, M.M. (2011). Access to financing and firm growth, Journal of Banking and Finance, 35(3): 709-723.

Reichstein, T. \& Dahl, M. S. (2004). Are firm growth rates random? Patterns and dependencies, International Review of Applied Economics, 18: 225-246.

Robson, P. J.A., \& Obeng, B.A. (2008). The barriers to growth in Ghana, Small Business Economics 30: 385-403.

Roberts, E. B. \& Berry, C. A. (1985). Entering new businesses: Selecting strategies for success. Sloan Management Review, 26(Spring), 3-17.

Ronstadt, R. (1984). Entrepreneurship. Dover, UK: Lord Publishing.

Roxas, H, Lindsay, V, Ashill, N \& Victorio, A. (2007). An institutional view of local entrepreneurial climate, Journal of Asia entrepreneurship and sustainability, 3(1): $1-28$

Rutherford, M.W., McMullen, P. \& Oswald, S. (2001). Examining the issue of size and the small business: a self-organising map approach, The Journal of Business and Economic Studies, 7(2): 64-81.

Sandberg, W. R., \& Hofer, C. W. (1987). Improving new venture performance: The role of strategy, industry structure, and the entrepreneur. Journal of Business Venturing, 2, $5-28$.

Schiffer, M \& Weder, B. (2001). Firm Size and the Business Environment: Worldwide Survey Results, IFC discussion paper number 43.

Scott, M., \& Bruce, R. (1987). Five stages of growth in small business, Long Range Planning, 20 (3): 45-52

Scase, R. \& Goffee, R. (1989). The real world of the small business owner. London: Routledge.

Schoonjans, B., Cauwenberge, P.V \& Bauwhede, H.V. (2013). Formal business networking and SME growth, Small Business Economics, 41:169-181 DOI 10.1007/s11187011-9408-6

Shepherd, D \& Wiklund, J. (2009). Are we comparing apples with apples or apples with oranges? Appropriateness of Knowledge accumulation across growth studies. Entrepreneurial Theory and Practice, 33:105-123.

Smallbone, D \& North, D. (1995). Targeting established SMEs: does their age matter?, International Small Business Journal, 13(3): 4-22.

Smallbone, D \& Welter, F. (2001b). The role of government in SME development in transition countries, International Small Business Journal, 19(4): 63-77 
Smallbone, D. \& Welter, F. (2001a). The distinctiveness of entrepreneurship in transition economies, Small Business Economics, 16 (4): 249-262

Smallbone, D. \&Wyer, P. (2000). Growth and development in the small firm, in Carter, S. and James-Evans, D. (Eds), Enterprise and Small Business, Prentice Hall, Harlow.

Sleuwaegen, L. \& Goedhuys, M. (2002). Growth of firms in developing countries, evidence from Cote d'Ivoire. Journal of Development Economics 68: 117-135.

Stam E (2010). Growth beyond Gibrat: Firm growth processes and strategies. Small Business Economics 35(2): 129-135.

Street, C.T, \& Cameron, A. F. (2007). External relationships and the small business: a review of small business alliance and network research. Journal of Small Business Management 45(2): 239-266

Steinmetz, L.L (1969). Critical stages of small business growth: when they occur and how to survive them, Business Horizons, 12(10): 29-36

Storey, D. J. (1994). Understanding the small business sector. London: Routledge.

Storey, D. \& Westhead, P. (1997). Management training in small firms - a case of market failure?', Human Resource Management Journal, 7(2): 61-71.

Tagoe, N., Nyarko, E., \& Anuwa-Amarh, E. 2005. Financial challenges facing urban SMEs under financial sector liberalization in Ghana. Journal of Small Business Management, 43 (3): 331-343.

Taketoshi, R., (1984). A Study on the Mergers in Japanese Manufacturing Industry. University of Tsukuba, Japan.

Thorelli, H. B. (1987). Entrepreneurship in international marketing: some research opportunities. In G.E. Hills (Ed.). Research at the marketing/entrepreneurship interface, Marrietta, GA: USASBE

UNCTAD, World Investment Report. (2000). United Nations Conference on Trade and Development, United Nations, New York, NY.

Uzzi, B. (1997). Social structure and competition in interfirm networks: the paradox of embeddedness, Administrative Science Quarterly, 42(1): 35-67

von Krogh, G., Sinatra, A. \& Singh, H. (Eds). (1994). The management of corporate acquisitions: international perspectives. London: The Macmillan Press, London.

Walsh, J. P. (1988). Selectivity and selective perception: an investigation of managers' belief structures and information processing. Academy of Management Journal, 31: 873896.

Watson, J. (2007). Modelling the relationship between networking and firm performance. Journal of Business Venturing, 22(6): 852-874

Wernerfelt, B. (1984). A resource-based view of the firm. Strategic Management Journal 5(2): 171-180.

Weinzimmer, L.G., Nystron, P.C., \& Freeman, S.J. (1998). Measuring organizational growth: issues, consequences and guidelines. Journal of Management. 24(2): 235-262.

Whetten, D.A. (1987). Organisational growth and decline processes. Annual Review of Sociology, 13: 335-358

Westhead, P, Cowling, M \& Howorth, C. (2001). The development of family companies: Management and ownership issues. Family Business Review 14(4): 369-385.

Wiklund, J., (1998). Small firm growth and performance. Entrepreneurship and beyond.

Dissertation, Jonkoping International Business School, Jonkoping, Sweden.

Wiklund, J. \& Shepherd, D. (2005). Entrepreneurial orientation and small business performance: a configurational approach. Journal of Business Venturing, 20: 71-91.

Wiklund, J. \& Shepherd, D. (2003). Aspiring for and achieving growth: The 
moderating role of resources and opportunities, Journal of Management Studies, 40(8): 1919-1941.

Wiklund J, Patzelt H and Sheperd DA (2009). Building an integrative model of small business growth. Small Business Economics 32(4): 351-374.

Yasuda, T. (2005). Firm growth, size, age and behaviour in Japanese manufacturing. Small Business Economics, 24 (1): 1-15.

Yli-Renko, H., Autio, E \& Sapienza, H. J. (2001). Social capital, knowledge acquisition, and knowledge exploitation in young technology-based firms. Strategic Management Journal, 22(6-7): 587-613

Vaessen, P., \& Keeble, D. (1995). Growth-oriented SMEs in unfavourable regional environments. Regional Studies. 29 (6): 489-505.

Zahra, S.A. (1993). Environment, corporate entrepreneurship, and financial performance: a taxonomic approach. Journal of Business Venturing, 8: 319-340. 